\title{
Harcosnők klubja? - Specializált társadalmi helyzetű nők a késő rézkor időszakában Magyarországon ${ }^{1}$
}

\author{
HORVÁTH TÜNDE² \\ Universität Wien Historisch-Kulturwissenschaftliche Fakultät Institut für Urgeschichte und Historische Archäologie \\ Franz-Klein Gasse 1, 1190 Wien, e-mail: tuende.horvath@univie.ac.at
}

\begin{abstract}
HoRvÁtH, T.: Fightress clubs? Women with a special social status in the Late Copper Age in Hungary.

Abstract: This article focus on the status of the woman in the main cultures (Baden complex and Yamna) of the Late Copper Age (3600-2800 BC) and the transitional period (2800-2600 $\mathrm{BC})$. Although the Bell Beaker complex belongs to the Early Bronze Age in Hungary (2500-1900 BC), in European terminologies it is a Late Neolithic culture and belongs to the Reinecke A0 horizon in its late phase, which is why I included it into my research. I identify charismatic people displaying signs of agression in these three culture complexes, whose personalities are associated with warfare. In all three cultures there were women with specialised status: their knowledge, property and profession raised them above the average man and woman.
\end{abstract}

Keywords: Late Copper Age, social structure, woman's social status, female warrior

\section{Bevezetés}

A tanulmányban azt vizsgálom, hogy a késő rézkor (3600-2800 BC) és az azt követő átmeneti periódus (2800-2600 BC) magyarországi két meghatározó kultúrájában, a Baden-komplexumban és a Gödörsíros kurgánok népénél az eddig előkerült régészeti eredmények alapján milyen volt a nők helyzete. ${ }^{3}$

Bár a Harangedényes népesség a magyar terminológia szerint kora bronzkori besorolású régészeti kultúra (2500-1900 BC, kora bronzkor 1/2 váltás-kora bronzkor 2a,b), ám Európa többi országában a késő neolitikum/ késő rézkor, illetve a kora bronzkor és a neolitikum/rézkor közti átmeneti időszakba, fémleletei alapján pedig a Reinecke A0(2300 BC előtt)-A1(2200 BC-től) horizontba tartozik ${ }^{4}$ - ezért európai besorolása miatt most ez a kultúrkomplexum is vizsgálatom részét képezi.

Az összehasonlítás alapja többrétű: egyrészt időben és térben egymás mellett élö, másrészt időben és térben egymást követő és átfedő kultúrákat vizsgálok, amelyekből következően eltérő szerkezetű társadal-

1 A címadás Chuck Palahniuk kultikus könyve és annak filmadaptációja után történt.

2 Post-Doc, Universität Wien, Historisch-Kulturwissenschaftlichen Fakultät, Institut für Urgeschichte und Historische Archäologie, Franz-Klein-Gasse 1, A-1190 Wien, e-mail: tuende.horvath@ univie.ac.at. A tanulmány megírása az FWF Lise Meitner ösztöndíjának keretében jött létre (M 2003-G25 project).

3 Horváth 2008 a Baden-komplexum komplett szociomorfológiai leírása, kitér a nők kivételezett helyzetére is, Id. a kebles edények-szoptatási ciklus kitolása-demográfia viszonyát: Horváth 2008, 184-189.

4 Ld. pl. Horváth 2013a: Budakalász-M0/12. lelöhely, a legnagyobb ismert sírszámú Harangedényes temetö kőeszközeinek feldolgozása; és Horváth 2015: A rézkor-bronzkor átmenet felmerülő problematikájáról. makat és bizonyos időbeli fejlödést is tanulmányozni lehet. Ugyanezt kisebb léptékü kultúrák esetében ( $\mathrm{pl}$. egy középső rézkori Balaton-Lasinja vagy egy kora bronzkori Makó kultúránál) nem lehet eredményesen vizsgálni adathiány miatt. Egy másik szempontból nézve a nők társadalmi helyzete csakis akkor válhat a mai kutató számára láthatóvá, ha mindez mellett a korabeli férfiak társadalmi helyzetét is ismerjük.

A tanulmány másik célja, hogy a kiemelt három kultúrában az agresszió és az erőszak jeleit felkutatva azonosítson olyan egykori karizmatikus embereket, akiknek személye meghatározó volt, és esetleg háborúskodással, csatározással, fizikai erőszakkal kapcsolatba hozható.

Ehhez azonban nem elég a tárgyi leletek vizsgálata, ugyanolyan hangsúlyos lehet ez mellett az ásatási megfigyelésekből származó információ. A feltárási körülmények sokáig nem voltak megfelelöek ahhoz, hogy olyan jellegű megfigyeléseket rögzítsenek, mint pl. egy mikrolit kőeszköz a testben, amely a halált okozhatta, vagy az elbomlott testeken a halál utáni másodlagos manipuláció nyoma. Magyarországon a balatonőszödi feltárás volt az első, ahol több ilyen megfigyelést tettünk. ${ }^{5}$ Nem véletlenül ezért néhány ismert eset kivételével ebben a tanulmányban ahol csak lehet, a saját feltárásaimra vagy a saját feldolgozásaimra támaszkodom, mégha ezek egy része mások feltárásán alapul is.

A megfigyelési problémakört tovább nehezíti, hogy ölni nyom nélkül, akár puszta kézzel is lehet, tehát a legkörültekintőbb módszerek alkalmazása mellett sem fogunk sikerrel járni és gyilkosságra utaló máig fennmaradt nyomot azonosítani minden esetben. Változást és előrelépést a finomodó feltárási módszerek mellett a DNS és izotópos vizsgálatok hozhatnak, amelyek segítségével eldönthetővé válhat, ki a helyi közösség tagja és ki idegen - vagyis potenciális ellenség vagy bevándorló. ${ }^{6}$

Fókuszba természetesen most is csak olyan esetek kerülhetnek, amelyek a régész számára különlegesek, tehát számunkra egyedi jelenségek és leletek. A ma különlegesnek tűnő esetek őskorra vonatkoztatott kivetítése állandó értelmezési veszélyforrás lehet: amit ma mi különlegesnek látunk, nem biztos, hogy a maga korában is az volt.

Végeredményként egyelőre csak annyi fogalmazható meg, hogy mindhárom vizsgált őskori régésze-

$5 \quad$ Horváth and Köhler 2012; Horváth 2014b.

6 A Balatonőszöd-Temetői-dűlői embertani anyagon 2013 óta folynak vizsgálatok az Uppsala-i laborban. 
ti kultúrában voltak a saját társadalmukban speciális helyzetet elfoglaló nők és férfiak is, akik mesterségük, vagyoni helyzetük, vagy egyéniségük, speciális tudásuk, anyagi javaik alapján saját korukban és még ma is jól láthatóan különböztek az akkori átlagtól. Mindezek a jelek mutathatják a társadalom kezdődő tagozódását még egy egalitárius társadalomban is, és természetesen jelentkeznek egy rangsoroló társadalmon belül. Ez a sztereotípia az emberi társadalommal egyidős, bármely korban és társadalomban előforduló jelenség. ${ }^{7}$ Agresszió és erőszak is bizonyíthatóan előfordul a paleolithikumtól kezdve, ${ }^{8}$ része lévén az emberi természetnek. ${ }^{9}$ Helytálló következtetések a vizsgált időszakra csak akkor adhatók, ha az előtte és az utána következő korszakok társadalmaival együtt látjuk, így az esetleges változások vagy hagyományok értékelhető, rendszerszintü tendenciaként jelentkeznek.

Arról, hogy a késő rézkor időszakában léteztek harcosok, sőt, talán már egyfajta intézményesített formában, szervezetten, nemzetközi tanulmányok értekeznek, elsősorban a Zsinegdíszes, a Harangedényes kultúrkomplexumok, és a Gödörsíros kurgánok esetében. ${ }^{10} \mathrm{~A}$ Badenben még nem mutattak ki ilyen réteget (vagy nem vizsgálták a kérdést ebben az aspektusban), bár a halmos temetkezések esetében felmerülhet a Gödörsíros analógia alapján (amely szintén csak feltevés), hogy társadalmilag magas pozíciót elfoglaló személyeket rejthetnek. ${ }^{11}$

\section{Időbeli, térbeli és kulturális keretek}

A három kiválasztott régészeti művelődés megegyezik abban, hogy mindhárom nemzetközi kutatást igénylő, ún. pán-európai, makro-regionális kultúra (kultúrkomplexum), Magyarország határain túl terjedt. Ez megkönnyíti a dolgunkat bizonyos szempontból, mert több és nem csak hazai adat áll rendelkezésünkre. Másrészt viszont megnehezíti, mivel a mindenkori aktuális, a tudományban is ható nemzetközi divatirányzattól nem tudunk eltérni. Ezért bár harcosnőket keresünk, látnunk kell mellettük a harcosokat is, és nem tudjuk nem érinteni a társadalmi és a nemi szerepeket, a specializációt, a kézművességet, a javak elosztását, az agresszió bizonyítékaként feltárt jelenségek mögött megnyilvánuló rítusokat, tehát a szakrális életet, és mivel az adatok legtöbbször temetkezésekből származnak, nem mentesülünk az éppen aktuális, alkalmazott temetőelemzési módszerektől sem.

A kora neolitikum óta stagnáló ill. mindössze kisebb változásokkal leírható, teljes népességcserével nem járó képet a középső rézkor vége (4000 és $3600 \mathrm{BC}$ közt) borítja fel radikálisan hazánkban. A késő rézkor egy egészen új világot hoz és felfokozott, több irányú és néha nagy létszámú, idegen eredetű népmozgást a

$7 \quad$ Etnográfiai példák Ember 1978; Harding 2007, 27-29; Helbling 2015, 69-83, a Baden-komplexumban Horváth 2008, 180-82

8 Vö. Vencl 1984, 120; Harding 2007, 41-45; Ferguson 2013, $196-$ 202; Meller and Schefzik 2015, 83-109.

9 Ember 1978; Harding 2007, 17-23.

10 Pl. Vandkilde 2006; Heyd 2007; Anthony 2007.

11 Sachße 2011.
Kárpát-medencében. ${ }^{12} \mathrm{~A}$ késő rézkor és az azt követő átmeneti periódus 3600 és 2600 BC közt régészetileg egységes korszakot alkot Magyarországon a Baden és a Gödörsírosok vonatkozásában. A 2600 BC-ként meghatározott, a korszakot másik irányból lezáró időpont még mindig nem hoz stabilitást: az azt követő kora bronzkor további, bár kisebb népmozgásokkal és rövid életű kultúrákkal írható le (pl. Makó, Nyírség), csak a végén kialakuló ún. tell-kultúrák (Hatvan, Nagyrév) megjelenése lesz olyan alap, amely az utána következő korszakokban is átöröklődve stabilnak bizonyul.

A vizsgált régészeti kultúrák elterjedése területileg és időben is részben egymást fedő, de kultúrájukat nézve nagyon is különböző, mivel mindhárom más életformára specializálódott, amely alapvető karakterét is adja mindháromnak.

A Baden-komplexum a Fekete-erdőtől a Feketetengerig húzódó kultúra, amelynek fő elterjedési vonalát a Duna adja. Változatos életterének határait a víz közelsége és a művelésbe bevonható földek jelölik $\mathrm{ki}$, lelöhelyeinek legnagyobb többsége valamilyen települési forma. A temetkezéseket néhány temető, és sok, a településeken belül előkerülő, rituális hátterü sír alkotja. Az embertani anyag alapján a kultúra déli kapcsolódást mutat, de sok benne a helyi elem is. Ez arra utal, hogy idegen népességek olvadtak össze különböző helyi, klasszikus középső rézkori bennszülött túlélőkkel, kialakítva a Baden-komplexumot. ${ }^{13}$

A Baden és a Gödörsíros kurgánok népe az Alföld területén kb. 3350 és 2600/2500 BC közt együtt él, bár lelőhelyeik többsége kikerüli egymást a különböző élettér igénye miatt: Baden lelőhelyek a jól művelhető talajokon, míg Gödörsíros kurgánok a kevésbé jó minőségű legelő-területeken kerülnek elő, a két élettér (ökológiai niche) néhány esetben, a mindkét fél számára az élethez elsődleges vízfolyások mentén, elsősorban pl. Dévaványa, Tiszavasvári, Békés települések térségében átfedi egymást, konkrét találkozásokat és interakciókat eredményezve a két kultúra között.

A Gödörsíros kurgánok népe az orosz steppék irányából terjedt nyugat felé. Magyarország területe a Tisza vonalával legnyugatibb elterjedési zónája a maga füves életterével. Csak temetkezési halmait ismerjük: sem a népes, nagy sírszámú „köznépi” temetők, sem pedig a szálláshelyek nem kerültek elő az Alföld területén. A temetkezési halmok alatt a kultúra előkelőit feltételezik, ez azonban régészetileg nem bizonyított. Erősíti azonban a feltételezést néhány kurgánon az alaptemetkezésnek szóló kősztélé, amely sematikusan ugyan, de az eltemetettet ábrázolja (általában férfit - de néha nőt is) az akkori viseletben: keresztszalaggal a mellkason vagy övvel a derékon, és fegyverekkel, mint pl. tőr/alabárd, fokos/balta, esetleg íj (ezek az elemek felbukkannak a Baden-idolokon is, a két kultúra integrációjának bizonyítékaként, és nyugat-európai sztéléken is, pl. az Alpok térségében). A portrékészítés az individualizmus, az egyéni dicsőség, a glória kialakuló-látható jele is a tisztelet és a társadalmi rangjelzés mellett. A probléma

\footnotetext{
12 Áttekintően Horváth 2014c; Horváth 2015.
}

13 Összefoglalóan Horváth 2014b, Section 3.3.1. 
az, hogy sztélék eddig a keleti területeken kerültek csak elő az egy mezőcsáti és egy újabb békési szórványlelettől eltekintve, és pontos datálásuk mindig problémákba ütközik - erre a legkorábbi Gödörsíros horizontra csak kevés keltezhető ikonográfiája alapján. ${ }^{14}$

A Gödörsírosok a Kárpát-medencében keletről érkező bevándorlók; robosztus embertani típusuk eltér a már itt élő, jóval gracilisabb bennszülött kultúráéktól. Az Alföldön a Badenbe ékelődve saját birodalmat alakítanak ki. A feltételezések szerint a Gödörsírosok egy hódító harcos-nomád lovas kultúra, amely patrónus-vazallus viszonyt épít ki leigázott környezetével. Ez azonban korántsem tükröződik a régészeti anyagban, és egyre inkább saját, 20. századi elképzelésünknek tűnik, legalábbis a nomadizmus ezen ismert legkorábbi időszakában. Az itt töltött letelepedett évek során a Gödörsíros embertani anyag keveredése azt mutatja, hogy lassan asszimilálódott a környezetébe. Ez arra utal, hogy kis létszámú hódító, idegen Gödörsírosok szivárogtak be, a bennszülött Baden települési tömbjébe ékelődve alapították ki szállásterületüket, és az elit dominanciáján át asszimilálódtak, lassan beleolvadva abba. ${ }^{15}$

A Harangedényes kultúra magyarországi lelőhelyei a Badenhez hasonlóan a Duna (és a Rába) vonalát követik, de szigetszerü csoportokban központosulnak a természetes folyami átkelőknél, és nem terjednek a Duna vonalánál tovább. Időben a 2500 BC körül feltünő legkorábbi Harangedényesek feltehetően az addig továbbélő, vagy az előtte néhány évvel eltünő Badent váltják Budapest térségében. Az azonosnak tűnő élettér azonban a Harangedény esetében mást jelent, mint a Badennél: kis átfedés lehet csak köztük, a Duna vonalát tekintve a víz jelentőségében (de a hajózás, kereskedelem és a szállítás terén, és nem létfenntartási okokból, mint a Badenben). ${ }^{16}$

A Harangedényesek magyarországi lelőhelyei kis lélekszámú, idegen hajós-kereskedő bevándorlók kolóniái: a kultúra elterjedési tömbjéről leszakadó előretolt harcos és hódító kereskedőtelepek, amelyek más, jóval népesebb kultúrák között kellett létezzenek, míg a Baden a saját elterjedési területén belül építette ki kereskedelmi és közlekedési csomópontjait a jól ismert, sokszor a Harangedényesekkel egybeeső folyóréveknél. ${ }^{17} \mathrm{~A}$ Harangedényes lelőhelyeket néhány, de jelentős település és ezekhez kapcsolódó nagyobb lélekszámú temető jellemzi (a Csepel-csoport területén), valamint egy különleges koponyaformával leírható embertani típus felbukkanása (tauríd, planoccipitális brachykran típus), amely jellegzetesen megkülönbözteti őket más magyarországi őskori kultúráktól (bár valamilyen, a két kultúra közti kapcsolódást jelenthet, hogy átkerül, ill. felbukkan a koponyatípus a kora bronzkori Kisapostag és Gáta-Wieselburg kultúrákban). ${ }^{18}$

\footnotetext{
14 Horváth 2014c, 524-526; valamint Harding 2007, 51. Legtöbbször másodlagos helyzetben kerülnek elö, ez is nehezíti értékelésüket és keltezésüket. Az in situ előkerülések többsége későbbi korszakokhoz kötődik, a Katakombasíros, és a Gerendavázas népességekhez.

15 Összefoglalóan Horváth 2011; Horváth 2014a.

16 Horváth 2013a; Horváth 2013b.

17 Horváth 2013b.

18 K. Zoffmann 2004, 387.
}

\section{Társadalmi keretek}

Nagy egyszerűsítéssel a középső rézkor előtti (1); a középső rézkor végétől a kora bronzkorig terjedő (2); majd a kora bronzkor utáni (3) időszakra bontom időben e tanulmány tárgyalt időszakait, amelyet társadalmi szinten a törzsi; a törzsi és a fönökségek közötti átmeneti; majd a fönökségi társadalmaknak feleltetek meg. Hangsúlyozom, hogy nagymértékủ egyszerüsítést kell végeznem, hogy tendenciákat és nagyléptékü, társadalmi szintű, strukturális változásokat tudjunk megfigyelni, tehát mind az időszakokat mind pedig a velük összekapcsolt társadalmi rendszereket egyszerüsítem amiatt, hogy lényegileg átláthatóvá váljanak. Valójában a neolitikum és a kora-középső rézkor időszak a törzsi társadalomnak (1) ${ }^{19}$ illetve a középső bronzkor a fönöki társadalmaknak $(3)^{20}$ való megfeleltetése jóval bonyolultabb, finomabb, és a mindenkori régészeti és kulturális antropológiai kutatásoknak megfelelően területenként, kultúránként és a kutatottság fokát tekintve eltéréseket és finom különbségeket mutathat. ${ }^{21}$

Számomra a leginkább viszont az a köztes, átmeneti időszak (2) a legérdekesebb, legbonyolultabb és a legnehezebben leírható, főleg a régészeti kultúrákra vonatkoztatva, amely a két nagy fejlődési egység között a törzsi társadalom lassú felbomlása és a fönökségi társadalom lassú kialakulása közti időszakot képviseli. Természetesen épp ez a 4000/3600-2600/2000 BC közti időszak a tanulmány tárgya, amelyet a Változás korának nevezek több tanulmányomban.

\section{Baden-komplexum}

Eddigi tanulmányaimban a Baden-komplexumra vonatkozóan egy olyan, még elsősorban vérségi (tehát családi) alapon szerveződő társadalmat rekonstruáltam, amely kisebb (talán nagycsaládi?) csoportokban, egy-egy vízfolyás mentén folytat mobilis életmódot (családi szállásterület, félig letelepedett, elsősorban állattenyésztő, juh- és szarvasmarha-tartó életmód, kiegészítve földmüveléssel). A letelepedési tömb egészét nézve a korabeli rendkívüli technikai vívmányok miatt (kerék, kocsizás, a szállítás és a kereskedelem gyors fejlődése) egyre inkább felbomló-félben levő törzsi rendet rekonstruáltam, amelyet a pan-tribal sodalities, vagyis a törzsek feletti együttmüködések fogalommal írtam le. Megfigyelhető, hogy a Baden-komplexumon belül a temetkezésben nem érvényesül a korábbi korszak szigorú, nemek szerinti megkülönböztetése: nincs tájolási és fektetési különbség a nemek közt (és ebböl következően a társadalom felépítésében sem). A mellékletadásban sem láthatók különbségek, sem a temetőkben, sem a településeken eltemetettek közt. A gazdasági élet gyökeres váltása (földművelés elsődlegességének feladása az állattenyésztés javára) leginkább az állandó, településektől elkülönült temetők számának csökkenésében, és a településeken belül elökerülö,

19 Vö. pl. Vandkilde 2006, 366-371; Parkinson and Gyucha 2007

20 Harding 2007.

21 Earle 2002 
különböző háttérrel elhunytak számának növekedésében látszik manifesztálódni. ${ }^{22}$

A teljes tárgyi anyag vizsgálata azt mutatja, hogy minden korábbi őskori kultúrától eltérően és azoknál sokkal nagyobb mértékben vannak a női nemhez kapcsolódó, elsősorban rituális jellegű tárgyak (idolok, női antropomorf kultikus edények) - tehát a női nem sokkal erősebben és karakteresebben reprezentálódik a Baden társadalomban. Ez egyértelműen a megerősödő női szerepeket jelenti (jelentsen ez társadalmi, politikai, gazdasági vagy vallási szerepet), esetleg a vérségi alapon szerveződő közösségek női/anyai vonalon való szerveződését. A Baden-komplexumot még egalitárius társadalomként írtam le, nem rangsoroló vagy rétegzett társadalomként, mert sem a temetők, sem a települések leletanyagában nem fordulnak elö tipikus, kötötten ismétlődő (nemhez/ranghoz/korhoz kötött) rangjelző tárgyak.

A fenti elképzelést erősíti, hogy kevés olyan leletet ismerünk a Baden-komplexumban, amelyek egyértelmüen rangjelző és presztízs-tárgyak lehettek a maguk korában. ${ }^{23}$

A pathológiai elváltozások és a mechanikai sérülések jelezhetnek életmódot, specializációt, harc, vadászat vagy hétköznapi baleset közben szerzett sérüléseket is (vö. a balatonőszödi 64. számú felnőtt férfin bordatörés; az 53. számú 23-29 éves férfin lábszártörés; a 41. számú felnőtt férfi koponyáján orrcsonttörés, ütés és vágásnyomok); ${ }^{24}$ és foglalkozásból eredő elváltozásokat is (feltűnő a 42. számú 39-43 éves kicsi-közepes termetű nő és a 79. számú 59-70 éves, kicsiny termetü nő karcsontjain a deltaizom tapadási helyeinek, valamint a felkarcsontok általánosan nagy mértékủ robosztussága amely nagy súly gyakori emelésével járó munkavégzésre utalhat; a 27. számú 23-27 éves férfi metszőfogain látható vízszintes irányú kopás pedig valamilyen növényi szálas anyag állandó rágása/ húzása közben alakult ki, talán gyékény, gyapjú vagy más anyag szövése-fonása közben, amelyet állandóan nyálazni és rágni, formázni kellett, hogy puha és szálas, tehát fonható maradjon). ${ }^{25}$ Budakalász-Luppacsárda 91. sírjában egy kőeszköz-készítő mester feküdt: 45-55 éves férfi (nő?) kő, csont és agyartárgyakkal. ${ }^{26}$ Balatonlelle-Felső-Gamász 17. sírjában az 50

22 Horváth 2008, 160-170; Horváth 2014b, Chapter 4.

23 Horváth 2008, 162-164. Tárgytípusonként: réz diadém, réz tör réz mellkas-ékszer, réz torques fordul elö. Különlegessége miatt ide sorolnám még a férfiarcot formázó portrészerű balatonőszödi maszkábrázolást is, bár agyagból készült: Horváth 2014b, Section 3.2.5. Az arc további érdekessége, hogy egy badeni településen a rekonstruálható arctípus alapján a Badeniek nem a saját embertani típusukat, hanem egy keleti arcot (Tripolje/Usatovo/Gödörsíros) formáztak meg benne, Id. Dani and Horváth 2012, 95.

24 További példák: Szombathely-Zanat-Trátai dűlő badeni településen, a 49. objektumban felnőtt férfi temetkezése, bal vállán gyógyult törés nyoma, jobb homlokcsontján $11 \times 13 \mathrm{~mm}$-es lyukasztott sérülés, amely a halálát okozhatta, mert gyógyulási nyoma nem látható: Tóth 2011, 100.

25 Horváth and Köhler 2012, 456-457.

26 Horváth 2013b, 334. Vadkanagyar-függője arra is utalhat, hogy nemcsak fegyverkészítő, de fegyvermester is volt. Érdekes, hogy az elsődleges nem-meghatározás ebben az esetben is kétséges: férfias nő, nőies férfi is lehet a fizikai antropológiai meghatározás alapján, akárcsak a vörsi és a budakalászi 616. sír.
54 éves férfi csípője alatt egy kupacban, feltehetően valamiféle szerves anyagból készült tartókészségben kerültek elő pattintott kőeszközök olyan minőségben és mennyiségben, amely alapján felvethető, hogy az elhunytban a közösség egy sikeres vadászát azonosítsuk. ${ }^{27}$ Ezt az elképzelést a talán vadásztrófeaként birtokolt vadkanagyar-melléklete is alátámasztja. Ami számunkra izgalmasabb, hogy a 22. női temetkezés hasonlóan pattintott kőeszközökben gazdag sírjában a 33-39 éves nő lábai alatt egy kupacban feltárt leletek a közösség egy, a 17. sírhoz hasonlóan sikeres és megbecsült vadásznőjét rejthetik. ${ }^{28} \mathrm{~A}$ kisebb, de településtöl elkülönült temető teljes elemzése azt mutatja, hogy több sírban előkerült ugyan fegyverként azonosítható nyílhegy, de átlag 2-2 db (9, 14, 21. sírok), ellenben a 17. és 22. sírok ebben a tekintetben extrém gazdagnak mutatkoztak, ezért emelhetők ki a fenti értelmezésben.

A balatonőszödi 37. számú 26-32 éves nő csigolyájába fúródott nyílhegy volt az első igazi bizonyíték arra, hogy a településeken feltárt badeni áldozati gödörtemetkezések esetében kétségtelenül fizikai erőszak áldozataival állunk szemben. Az eset kivételességét és érdekességét tovább erősíti, hogy feje hiányzott, helyén egy felnőtt, 23-27 éves férfi (95. temetkezés) koponyáját tártuk fel, amely a halál utáni, a testtel végzett másodlagos manipulációkat bizonyítja (fejcsere=személyiségcsere?). ${ }^{29}$

A felsorolt esetek egy része településen belül, áldozati gödrökben került feltárásra, amely tovább bonyolítja értelmezésüket, és elsődlegesen szakrális-rituális megközelítést ad nekik, bár nem zárja ki azt a lehetőséget (másodlagosan), hogy háborús konfliktusok áldozatai voltak, és így kerültek feláldozásra. Arra a kérdésre, hogy saját közösségükön belül kerültek-e kiközösítésre vagy idegen ellenségekként, fogolyként végezték úgy, mint emberáldozat, csak a jövőben végzett genetikai/ izotópos vizsgálatok adhatnak végleges választ. ${ }^{30}$

\section{Gödörsíros kurgánok népe}

A Gödörsírosok társadalmának rekonstrukciója jóval nehezebb, mint a Badené a települések hiánya és a leletanyaguk csekélysége miatt. Le kellett számolnom fél évszázados mítoszokkal is, amelyek megdőltek velük kapcsolatban (pl. a lótartás és az ezzel kapcsolatos háborús férfi lovas arisztokrata réteg létezése). A Gödörsíros társadalom véleményem szerint még szintén egalitárius, vérségi alapon szerveződő, kiscsaládi közösségekböl épült fel, amelyek viszont - ellentétben a Badennel - patriarchális vonalon szerveződtek. Teljes mértékben mobilisak és állattartók voltak, a Badenhez hasonlóan vízfolyások mentén vándoroltak, pontosabban pásztorkodtak. Bár nomád társadalmuk miatt az értékek számukra egészen mások lehettek,

27 Nagy 2010, 460-469

28 Nagy 2010, 480-487.

29 Horváth and Köhler 2012, 456. Talán annak, hogy egy másik személy feje került az eredeti helyére, köze van a badeni idolok cserélhető fejüségéhez is - megint ugyanazzal a rítuselemmel állunk szemben egy másik kontextusban, a valódi halottak világában.

30 Horváth and Köhler 2012, 456-461; Horváth 2014b, Section 3.2.2. 
mint a Badenben (elsősorban a legelők, állatok és a könnyen mozdítható javak, pl. ékszerek, fegyverek jelentettek értéket) és ezzel nagy hatást gyakoroltak a Badenre, kis számuk miatt azonban mégis ők olvadtak be a Badenbe, és nem fordítva.

A keleti steppéken előkerült kurgánsírokban specializáció, szakosodott kézmüvesek rétegének megjelenése is kimutatható - sajnos hazánkban ezek a leletek egyelöre hiányoznak. Az Akszáj-i kurgánban például egy 18-20 éves nő sírjában kerültek elő fémműves mesterre utaló leletek (öntőtégely), Pershinben pedig egy 12-13,5 éves fiú kurgánsírjában tártak fel öntőmintát. ${ }^{31}$ Ezek a kivételes esetek bizonyítékai annak, hogy a különleges tudást és egzotikus anyagokat igénylő mesterségeknek kialakultak a saját mestereik: fémtárgyat már nem készíthet bárki, mint pl. egy kőeszközt. Ugyanakkor az is világos e példákon keresztül, hogy a mesterségek nem köthetők korhoz és nemhez, esetleg a tudás és a mesterség becses hozzávalói és tudása családon belül örökölhetővé vált, függetlenül kortól és nemtől, ha nem volt felnőtt férfi leszármazott.

\section{Harangedényes-komplexum}

A Harangedényes társadalom az előző kettőtől eltérően már rangsoroló (vannak rendszeresen adott és szabályossággal előforduló presztízs-tárgyai a sírmellékletek közt, némelyik harci trófea lehetett, vö. vadkanagyar). Bár még nem mutatja a kialakult főnökségi társadalom jeleit (elsősorban talán azért, mert nem a törzsterületét vizsgáljuk Magyarország esetében, hanem egy attól leszakadó elszigetelt, kisebb kolóniát), de talán már nem (csak) vérségi, hanem haszonelvi és egyéni kvalitások alapján szerveződő kereskedőtelepekként létezik Magyarország területén. A lótartást, a sörkészítést-terjesztést és -ivást, összekapcsolva a speciálisan erre a célra gyártott harang alakú edénynyel, mint annak göngyölegével, valamint az európai bronzmúvesség kialakulásában játszott, korábban a Harangedényeseknek fenntartott vezető szerepet azonban vitatnám a leletek és a bizonyítékok egyértelmü hiánya és a felbukkanás korai időpontja miatt. ${ }^{32}$

A csontvázas temetkezésekben újra megjelenik a nemi dimorfizmus a fektetésben, viszont ez a mellékletadásban már nem érvényesül. Előfordul a halomemelés is, mint esetleges rangjelzés, bár ezek rendszerint elpusztultak, csak körárokként marad nyomuk. A helyi közösségekkel való asszimiláció és interakció jele lehet a sokféle alkalmazott vegyes temetkezési rítus (hamvasztásos, szórt-hamvasztásos és csontvázas rítus is előfordul Magyarországon, a halomemelés is idetartozhat). A harc és az egyéni hódítás, tehát az individualizáció kezdeti jele lehet a gazdag mellékletekkel ellátott, de halottat nem tartalmazó sírok (kenotáfium) viszonylag sürü előfordulása, amelyet a várnai középső rézkori temető után úgy értelmeznek,

31 Bátora 2002, 183, 187

32 Pl. Horváth 2014a, 103-113, amelyben a Gödörsíros lótartás, lovaglás, lovas harci kultúra létét is cáfolom. Hasonlóan óvatosságra int Helle Vandkilde is, a Harangedényes mellett a Zsinegdíszes kultúrával kapcsolatban is elterjedt ezen sztereotípiáról: Vandkilde 2006, 372-375 mint idegenben elesett hódítókat/harcosokat, akiknek a testét nem tudták hazahozni és eltemetni. ${ }^{33}$

\section{Harcosok, háborús konfliktusok azonosítása}

A témában született nagy hatású munkák megegyeznek abban, hogy a háború intézménye, úgymint az erre szolgáló fegyverek, az ennek nyomán kialakult speciális társadalmi csoportok és az azokat kiszolgáló klubok, társaságok a késő rézkor végén, 3000/2800 BC körül születnek meg és terjednek el Európa területén, elsősorban a Zsinegdíszes majd a Harangedényes kultúrákban, és azok hatására. ${ }^{34}$

A régészeti leletanyagban ezek a jelek többféleképpen manifesztálódhatnak.

\section{Fegyverek}

A korszak vezető, ám már a paleolithikum óta létező fő fegyvere az íj és a nyíl. Az, hogy ez a fegyvernem egy egyszerü vadászkészségböl (amely néha persze védelmi vagy támadó célokat szolgáló fegyverré is válhatott, Id. Balatonőszöd, 37. temetkezés esetét) harcos fegyverévé vált, a Harangedényesek között történt meg. ${ }^{35}$ A társadalmi változásoknak köszönhette felemelkedését és megváltozott szerepkörét. A Harangedényeseknek muszáj volt új területeket foglalniuk hódító kereskedelmi szándékaik eléréséhez, idegen környezetben, és ehhez megfelelő háttér kellett: hozzávaló gyors, mozgékony, de teherbíró hajók (amelyekröl semmi konkrétumot nem tudunk) és fegyver, amivel támadhattak és védekezhettek.

A korszak másik fegyvere a csiszolt kőből készült csatabárd és a buzogány, amely elsősorban a Zsinegdíszes kultúrában terjedt el. Későbbi alapos vizsgálatuk azonban óvatosságra int abban a tekintetben, hogy nem minden esetben voltak valódi használati fegyverek vagy kettős célt is szolgálhattak: sok közülük sírmellékletként csak szimbolikus értékkel bírt és reprezentációs célokat szolgált, más esetekben nehéz eldönteni, hogy fegyver-eszközök vagy eszköz-fegyverek voltak. ${ }^{36}$

Ugyancsak meg kell emlékeznünk az ekkor már pl. a Mondsee kultúrában és a Badenben is feltünő kisméretü, harcra még alkalmatlan tőrökröl, ${ }^{37}$ a nagyobb tőrökröl, amelyek alabárdként is szolgálhattak (és amely Sárrétudvari 7. Gödörsíros kurgánjában is előfordult), csákányokról, baltákról, fokosokról (az ún. Bányabükk-Fajsz típus a Kárpát-medencében, illetve Remedello kultúra leletei Itáliában), amelyek még rézből készültek, de ábrázolásuk sztéléken, sziklavéseteken, idolokon is feltűnt, tehát presztízs-jelzők lehettek. ${ }^{38}$ Gyártásuk tökéletesedik és bronzból készülve a további korokban is nagy szerepet játszanak, mint tá-

33 Vandkilde 2006, 366-367

34 Vandkilde 2006, 357; Harding 2007

35 Stambowski 2015

36 Zápotocky 1992; Chapman 1999, 107-110; Vandkilde 2006, 366 Harding 2007, 46-47.

37 Horváth 2015, 120; továbbá Kántorjánosi: György 2012, 11-113. 38 Vö. pl. Kerig 2010. 
madó és védő-fegyverek, presztízs-szimbólumok. ${ }^{39}$ Ötzi, a Jégember felszerelései közt is megtalálhatók ezek a tárgytípusok, sőt, előkerülésük környezete arra utal, hogy ő maga is egy csetepaté áldozata lett 33003110 BC között. Mindettöl függetlenül senki nem gondolja a Hauslabjoch mellett, magashegyi környezetben előkerült késő rézkori jégemberröl, hogy a maga korában harcos vagy előkelő lett volna, éppen a lelet tökéletes épségben maradt, ezúttal tényleg teljes teste és felszerelése miatt. Ez az előkerülés mélységesen el kell, hogy gondolkodtasson bennünket azokban az esetekben, amikor temetők sírjaiban talált tucatnyi hasonló felszerelés számos előkerülése után ezeket publikációinkban harcosoknak vagy rangos temetkezéseknek nyilvánítottuk (vö. pl. Bodrogkeresztúri, Lengyeli kultúrák „gazdag” sírjai). Ötzi nem volt harcos, sem fönök vagy akárcsak Big Man, személyét leginkább harcban, konfliktusban elhunyt áldozatként értelmezik. Lehetett viszont életében pásztor, bányász, hegyi vezető és vadász - valamennyi egyszerre, ha arra szükség volt, aki, ha kellett, emellett harcolt is az éppen aktuális ellenségei ellen, akik akár még a saját közösségéből is kikerülhettek. ${ }^{40}$

\section{Erődített települések}

Több szerző evidensen összekapcsolja az ellenség fenyegetését, a szervezett hadviselés létezését a támadás kivédése érdekében épített erődített települések megjelenésével, ${ }^{41}$ én azonban ezt illetően - akárcsak a temetkezési halmok esetében azok evidens összekapcsolását a magas társadalmi státusszal - szkeptikus vagyok. Elképzelhetőnek tartom azt, hogy az erődítés óriási munkája mögött egyik okként talán a védekezés és a biztonság képzetének megteremtése állt, amelyet kiválthatott egy egykori valódi támadás vagy attól való, akár ok nélküli rettegés, de más okokat is el tudok képzelni, amelyek ugyanolyan fontosak lehettek. Bizonyított ugyanis, hogy bizonyos közösségek szociális és lelki életében nagy szerepet játszhat egyfajta látszat megteremtése, a valós vagy vélt megalománia kifejezése és a „másoktól különbek vagyunk” érzése - az olyan erőfitogtatás, amely a valóságot messze felülmúlja. Ezek a lélektani tényezők is közrejátszhatnak a hatalmas közösségi munkák eredményeképpen, akár több évszázadon keresztül épülő sír-, erődítési vagy egyéb (pl. csillagászati obszervatórium) céljára szolgáló, közösségi munka során születő építmények emelésében a megtámadottság és a védekezés érzése mellett vagy azt akár teljesen kizárva. ${ }^{42}$

39 Zich 2015; Maraszek 2015.

40 Harding 2007, 48-49.

41 Vandkilde 2006, 366. A Baden-komplexumban is számon tartanak magaslati, erődített telepeket: Id. Horváth 2004, 64. Ezek revíziója során ÉK-Magyarország térségében azonban kiderült, hogy sem nem magaslatiak, sem pedig erödítettek nem voltak (Horváth 2018). A Dunántúl területén fekvő potenciális lelöhelyekröl egyelöre még nem tudok nyilatkozni.

42 Dani and Horváth 2012, 121-122.

\section{Halom-emelés sírépítmény céljából}

A társadalmilag magas státusz kifejezésének egyik formája lehet a halotti rítusok között megjelenő halomépítés szokása. Úgy gondolom azonban, hogy az ide tartozó esetek mindenkor egyéni vizsgálat tárgyát képezik. Az atlanti megalithikus sírok esetében például semmi köze nincs ehhez. A pre-Gödörsíros, korai Gödörsíros melléklet nélküli sírok esetében sem látom egyértelmüen ezt, bár nem zárom ki lehetőségét. A halom-emelés a teljesen mobil társadalmak esetében szolgálhat a temetkezési rítuson kívül olyan egyszerü, profán célt is, hogy egy stabil térbeli és időbeli pontot képezzen a közösség mindig mozgással telő életében; ahol sokáig, rendszeresen összegyűlhetnek és megemlékezéseket tarthatnak. Ahová, mert megjelölték, mindig visszatalálnak, mert ugyanúgy benne él a kollektív topográfiai tudatukban, mint a valós tájban. Újratemetkezhetnek benne, vagy a halott évfordulóján újabb emlékezést segítő fesztivált tarthatnak rajta. Másik halottnak új halmot emelve, állandóan terjeszkedve, bővülve velük térben és időben (kurgánmező), valamint mentálisan és szakrálisan is, mementóként szolgálnak - tehát egyszerre több célt is - a leszármazottaknak. Nagy valószínűséggel azokban az esetekben, ahol sztélé-állítás is kapcsolódik hozzá, gazdag melléklet-adással, már státuszszimbólum is lehet. ${ }^{43}$

A kőből épülő kisebb Baden sírhalmok esetében az építés mögött az az egyszerü tény is állhat, hogy talajban szegény vidéken mindössze le akarták takarni az elhunytat a szokás szerint, de a talaj helyett rendelkezésre álló kő eltérő építési technikát igényelt (Ózd-Piliny csoport).

\section{Tömegsírok, kannibalizmus, traumák nyomai a csontokon, halál utáni manipulációk, fejvadászat, koponyakultusz, agyvelö-evés}

A felsoroltak ugyan a megnyilvánuló erőszak jelei lehetnek, de korántsem egyértelműen a háború jelenségéhez köthetők. ${ }^{44} A$ háttérben ezt előidéző motiváció sokféle lehet, és több közülük kizár mindenféle ellenséges szándékot és harci kedvet, háborúzást.

Az őskori tömegsírok többségéről sajnos az előkerülési körülmények és a gondos régészeti-antropológiai feldolgozás után sem lehet biztosat állítani. ${ }^{45}$ A Badenben rendszeresen fordulnak elő többes temetkezések a településeken belüli temetkezésekben

43 Összefoglalóan Horváth 2015, 111-112.

44 Az ilyenfajta tömegsírok tipikusak a Vonaldíszes kultúrától, vö. az egyik leghíresebb lelőhely, Talheim példáján: Wahl-Trautman 2012. Magyarország területén a legkorábbi az Esztergályhorvátiban elökerült, Lengyeli kultúrához köthető jelenség: P. Barna 1996. Hasonló, településeken feltárt tömegsír lehet, amelyet csatározáshoz kötnek az Altheim csoport névadó földvárában: Saile 2014, amely a Badent közvetlenül megelöző középső rézkori időszakkal párhuzamosítható; valamint a Bernburg kultúrába tartozó Gotha lelőhelyen: Beier 1983. Még a késői Badennel részben egyidős Gömbamfórás kultúrában is elöfordul, mint jelenség, Id. Konopka et al. 2016: az 523. sírban 15 egyedböl 12 koponyáján volt éles, vésőbalta okozta halálos sérülés, 2875-2670 BC; de ismert a Zsinegdíszes kultúrában is: Id. Eulau híres esetét: Meyer et al. 2009.

45 Kivételes példa egy 1200 BC körüli bronzkori, folyó menti háborús csatahely előkerülése, amely már a feltárás során árulkodott erről az értelmezési lehetőségről: Jantzen et al. 2011. 
és ritkábban a temetők sírjai közt is, de tömegsírként egyedül a balatonőszödi 1099. kútba másodlagosan bedobált tíz egyedet említeném meg példaként (1. ábra). A jelenség kivételessége, hogy ez az egyetlen olyan áldozati/temetkezési objektum Balatonőszödön, amely nem a tűzhöz, hanem a vízhez kapcsolódik, és mélyen a talajba ásva a lenti, alvilági, chtonikus erőkkel társítható (fekete mágia?). ${ }^{46}$

Kannibalizmus kialakulhat kényszer hatására is (éhezés, bevitt fehérjeforrás-hiánya, a helyi állatfauna szegényessége, stb.), amelyet beépíthetnek a rítusok közé, hogy saját maguk számára is magyarázhatóvá váljon (ősök vagy ellenség „tiszteletből” vagy hatalomvágyból való elfogyasztása), de kísérője és rituális, ünnepélyes lezárója lehet a háborúzásnak, csatározásnak is. ${ }^{47}$

A csontokon látható fizikai elváltozások egy része ugyancsak keletkezhetett a hétköznapi élet, rítusok vagy balesetek során is, kevés köztük az egyértelmü. (Beavatás a szellemek világába?: a 41. számú balatonőszödi férfi koponyáján látható felületi és rendszert mutató vágások nyomai inkább csak megjelölték, mint megsértették vagy gyógyították az egyént. Ellenben a behorpadás már szándékos ütéstől származik, és elváltozásainak, sérüléseinek összessége azt sejteti, hogy közösségének nagy vadásza/harcosa lehetett, mert kivételesen sokszor sérült meg, bár mindet túlélte. Temetése is különleges volt, mert teljes testét kerámiapakolás fedte, amely nem általános a Badenben. ${ }^{48}$ )

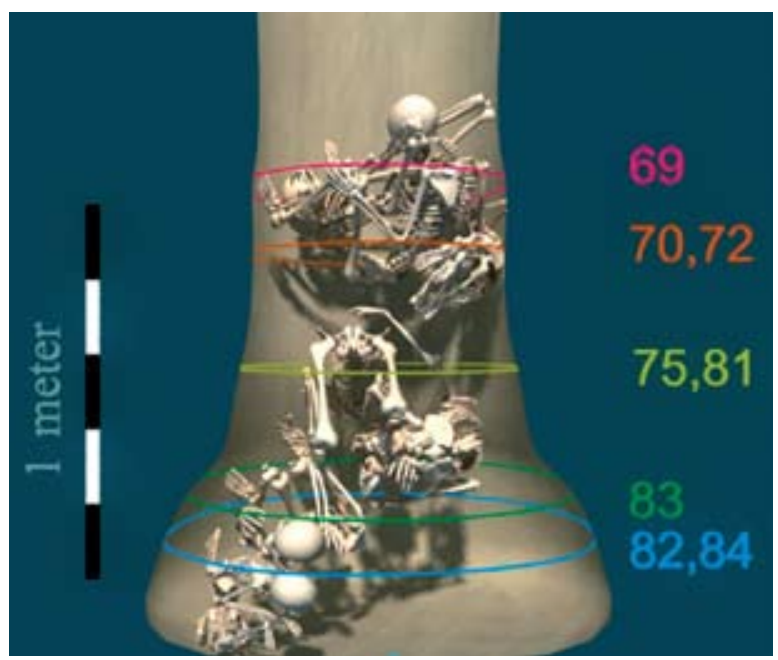

1. ábra. Balatonőszöd-Temetői dülö, a 1099. kút rekonstrukciója (készítette Réti Zsolt)

46 Horváth and Köhler 2012, 455; Horváth 2014b, Section 3.2.2.

47 Diamond 2010, 147-157, 198, 297-323.

48 Horváth and Köhler 2012, 456-458, Fig. 4. Hasonló elképzelést vetettek fel a késő rézkor eddigi egyetlen bolerázi kultúrába sorolható trepanált koponyája esetében, amely Zillingtalon került elö: Kritscher 1985
A halál utáni, testtel végzett manipulációk, ${ }^{49}$ fejkultusz/koponyakultusz, ${ }^{50}$ az agyvelő elfogyasztása ${ }^{51}$ elsősorban úgyszintén rituális motiváció, és az őskori esetekre kivetítve lehetetlen eldönteni, hogy mely esetekben történt meg valamelyik egy egykori ellenséggel, amely csatározáshoz köthető, és mely esetben a saját közösségén belül valakivel, akit egyszerűen csak kválasztottak vagy kiközösítettek, és feláldoztak egy emberáldozatot követelő rítus alkalmával. ${ }^{52}$

\section{Étel-, ital- vagy fegyver-raktárleletek}

Azokban a társadalmakban, ahol különböző célokkal alakult női- és férfi-társaságok müködnek, gyakori, hogy a csoport-összetartozást és öntudatot tudatosan erősítik például sajátos viselettel különböztetve meg magukat másoktól, vagy közös lakomákat és italozást rendezve. Az utóbbi alkalmak régészeti lenyomatai lehetnek az önálló edény-raktárleletek elsősorban ivásra szolgáló edénytípusokkal, amely a Badenkomplexumon belül csekély számban előfordulnak. ${ }^{53}$

49 Mind a Baden-komplexumban, mind a Gödörsíros kurgánok köz előfordulnak a testtel végzett halál utáni manipulációk, a fej és a végtagok eltávolítása és más objektumban való felbukkanása. Balatonlelle-Felső-Gamász 291. sírjában a férfi testét csípőben elvágták a temetés után, és a töle 1,5-2 méterre fekvő 117. gödörbe helyezték át: Horváth and Köhler 2012, 461; Nagy 2010, 474-480. Azért említem meg ezt a kivételes esetet sok más létező mellett, mert itt mindkét objektum, valamint az összes testrész és azok egymáshoz való viszonya elökerült és vizsgálhatóvá vált, míg legtöbbször vagy a törzs vagy a szeparált testrészek kerülnek elö, egyik a másik nélkül.

50 Önálló koponyatemetkezések a Baden-komplexumban többször előfordulnak, de ezt még nem nevezném fejkultusznak vagy koponyakultusznak, amely bizonyos esetekben háborúskodáshoz kapcsolható (az ellenség fejével való rituális manipuláció: trófeának való megszerzése a győztes jutalma). Más esetekben, saját közösségen belül, a halottkultusz részeként a vezetőknek vagy az ősöknek szánt tisztelet jeléül is készíthetnek fej- vagy koponya-trófeákat. A fej és a végtagok máshol való eltemetése és a testtő való leválasztása a Baden rendszeres halotti rítusai közé tartozik, amely szorosan kötődik és egységet képez más rituális elemével is: a kultikus célra szánt antropomorf szobrocskák is fej és végtagok nélkül ábrázolják az embert: Horváth 2014b, Section 3.2. A steppén a Katakombasírosokra jellemző a fejjel való modellezés (agyag, kátrány, okker és egyéb anyagok felhasználásával maszk készítése): Dani and Horváth 2012, 71. A feltételezések szerint a nomádok csak a nyári szálláson temettek: aki télen halt meg, annak testét valahogy „konzerválták” addig, amíg a nyári legelőkre értek és temethettek. Ezért bizonyos konzerválási beavatkozásokat kellett végezni a testen, hogy állapota megfelelő legyen a nyári temetéshez. Ennek egyik eleme lehetett az arc agyaggal való modellezése: Davis-Kimball 2002, 89.

51 Balatonőszödön egy esetben került elő koponyatöredék pörkölés nyomaival, amely az agyvelö elfogyasztására utalhat (2480. gödör, 68. temetkezés): Horváth 2014b, Section 3.2.2, 158, Fig. 132.

52 Horváth and Köhler 2012; Horváth 2014b, Section 3.2; Alt and Friedrich 2015. A 4300-3600 BC közt élö Michelsberg kultúrában viszont egészen biztosan létezett fejkultusz és koponyakultusz (bár az még kérdés, hogy idegen ellenséggel vagy belső emberekke történt), amelyet nemcsak a koponyákon feltűnő trepanálások, hanem az arckoponyarészből leválasztott és megmunkált rituális koponyamaszkok is bizonyítanak: Wahl 2010. Emberáldozaton való feláldozottak között az eddigi források alapján lehettek idegenek, a saját közösségen belül pedig bűnözők és a társadalom perifériáján élők (tehát egyfajta büntetés és igazságszolgáltatás részét képezte), de voltak olyanok is, akiket éppen magas státuszuk miatt választottak ki erre a szerepre, és azt megtiszteltetésnek tartották.

53 Edény raktárleletek: Donnerskirchen-Kreutberg, Dřetovice: Horváth $2008,171,31$. lábjegyzet. 
A Harangedényes kultúrában néhány pattintott kőeszköz-raktárlelet elökerülése utalhat a felhalmozás jelentőségére és a fegyverek vagy nyersanyaguk jelentőségének növekedésére. ${ }^{54}$

\section{A három vizsgált kultúrában előforduló konkrét esetek ismertetése}

\section{Baden-komplexum}

Komplett temetőelemzések még nem végezhetők a kultúr-komplexum esetében, amelyben összehasonlíthatóvá válna a férfi és a női nem közti különbség, mert a budakalászi temető 1950-es évekbeli feltárása és 2010-es publikálása között sok adat és lelet odaveszett és a megfigyelések dokumentálása nem volt a mai elvárásnak megfelelő, a balatonlellei temető pedig ehhez túlságosan kis létszámú (23 sír). A településeken előkerült temetkezések azért nem vonhatók be az ilyesfajta értékelésbe, mert ott többféle háttérrel temethettek, nemcsak természetes elhalálozáskor, ezért demográfiai elemzésre is alkalmatlan. Egyedi esetek emelhetők csak ki, amelyek során most csak a női és a valóban figyelemreméltó jelenségeket sorolom.

- Vörs-Majorsági-épületek (2. ábra): a ma már csak a koponyából és az azon található réz diadémból álló leleten 2005-ben végeztettem antropológiai vizsgálatot, amelynek során kiderült, hogy a szakirodalomban főnökként, törzsföként, sámánként elhíresült férfiszemély valójában nő, és még nem végeztek eddig rajta semmilyen antropológiai meghatározást. Ennek a felfedezésnek a jelentősége óriási, mert a vörsi nő olyan presztízstárgyat visel, nőként, amely az összes eddig előkerült Baden temetkezés fölé emeli. Ténylegesen lehetett közösségének vallási, társadalmi vagy bármilyen vezetője egy nő, amely az őskor időszakában a Kárpát-medencében egyedülálló. ${ }^{55}$ Kérdés, hogy kétágú, szarvakban végződő egyszerü pántdiadémja, amelyet poncolással díszítettek, minek mutatja őt valójában: erre vonatkozó értelmezések még nem születtek (vö. Állatok Úrnője? ${ }^{56}$, ill. annak papnője?).

- Balatonlelle-Felső-Gamász, 22. számú zsugorított csontvázas 33-39 éves nő sírja (3-4. ábra): az ásató feltételezi, hogy kirabolták a sírt. Mellékletei: nyakánál három rézgyöngy, lábától kb. $10 \mathrm{~cm}$ rel lejjebb, egy kb. $20 \times 30 \mathrm{~cm}$-es területen hat kovanyílhegy, valamint egy hetedik a bal bokájánál. A nyílhegyek csúcsukkal nem egy irányba néztek. A bal bokacsonttól kb. $5 \mathrm{~cm}$-re jobbra két összetartozó őrlőkő. A koponyától közvetlenül följebb egy tál, benne állatcsontok. A sírgödör déli felében a gödör bal oldali széle mentén, a csontváztól kb. 20-50 cm-re balra, a csontváz szintjétől kb. $20 \mathrm{~cm}$-rel magasabban egy földpadkán egymás mellett edények és néhány egyéb lelet volt. A gerinc felső részével egy vonalban öt bögre egy halomban, eredetileg valószínüleg össze voltak füzve. Ettől lejjebb egy vörös festékkő, jobbra mellette pedig egy kova magkő feküdt. A bögrék mellett, azok-

\footnotetext{
54 Horváth 2013a, 167

55 Horváth 2008, 183-184, Abb. 2; Köhler 2015.

56 Counts and Arnold 2010
}

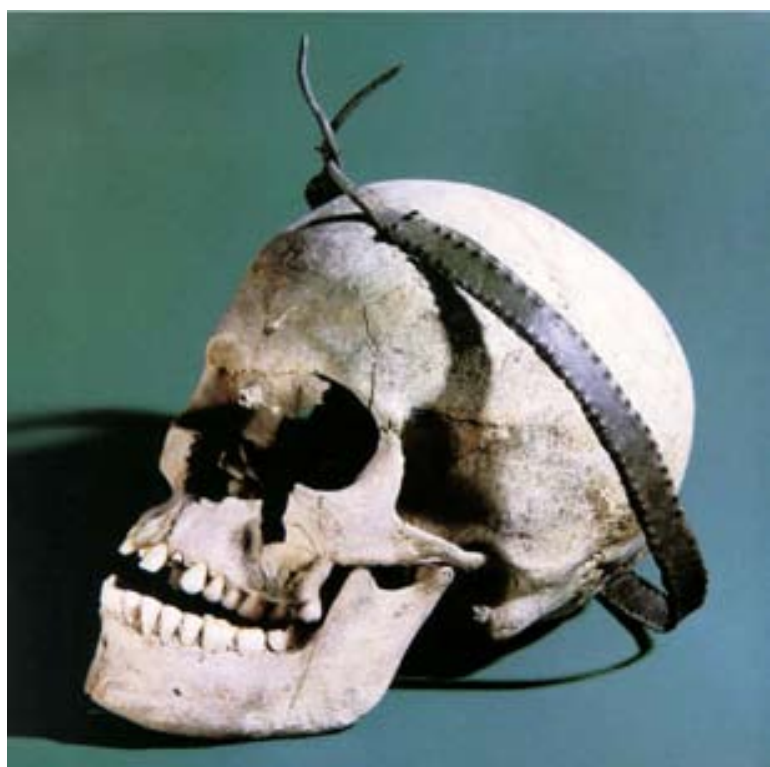

2. ábra. Vörs-Majorsági-épületek, diadémás női sír. (A MTA-BTK Régészeti Intézetének fotógyüjteménye, Kádas Tibor)

tól följebb, a koponyával kb. egy vonalban egy tál, benne pedig egy töredékes állapotú kisebb, szalagfüles tálka. Ezektöl közvetlenül följebb egy tálfazék volt. Följebb lévő részének egy nem teljesen vízszintesen fekvő, ép korsó támaszkodott. Ettől följebb, a gödör DK-i végében egy másik tálfazék volt. A gödör széle felé eső részén erősen összetört állapotban lévő kétfülü fazék volt. ${ }^{57}$

- Balatonőszöd-Temetői-dűlő (5. ábra): A 1489. áldozati gödör hat individumot őrző többes temetkezés: újszülött és három további kisgyermek csontvázát, egy nő csontvázát (37. csontváz) és egy férfi koponyáját (95. koponya) tartalmazta, amelyek együtt alkotottak egy teljes kompozíciót. A női csontváz gerincébe ékelődve háromszög alakú nyílhegyet találtunk, amely a halálát okozhatta. A gödörben nagy valószínüséggel egy család tagjai nyugszanak, biztosat viszont csak a DNS vizsgálatok után mondhatunk. Az izotópos vizsgálatok talán választ adnak arra a kérdésre, hogy a saját közösségükhöz tartoztak-e, vagy idegenek voltak, akiket lemészároltak. ${ }^{58}$

Következtetésként levonható, hogy a Badenkomplexumban nemcsak a különleges leletek, de a temetkezések között is megjelennek azok a rangos női személyek, akik demonstrálják a férfi mellett a női nemnek is szánt társadalmi vezető szerepeket.
57 Nagy 2010

58 Horváth 2014b, 135-136. 

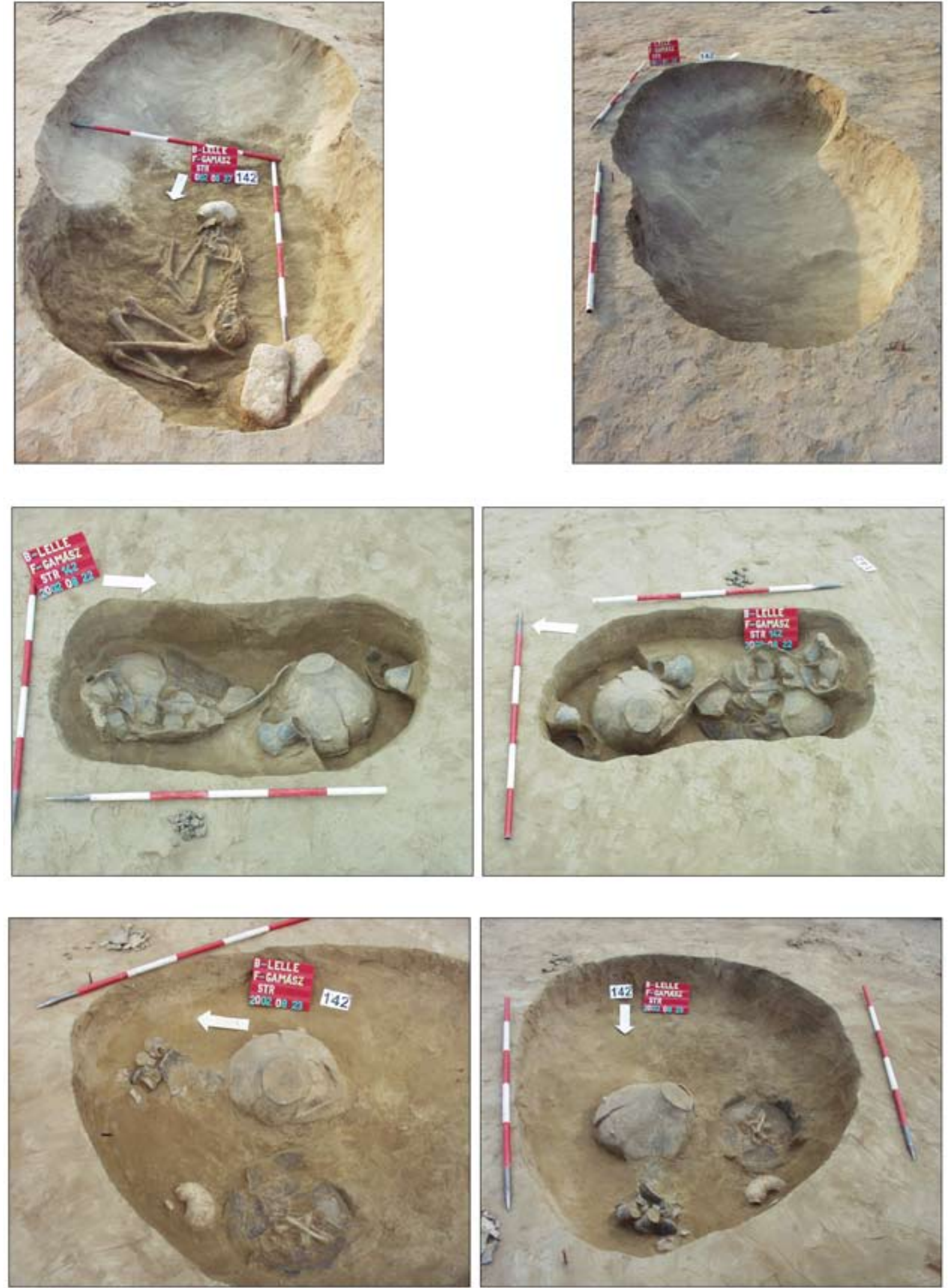

3. ábra. Balatonlelle-Felsö-Gamász, 22. női sír: sírfotók. (Nagy Borbála engedélyével, saját képei) 

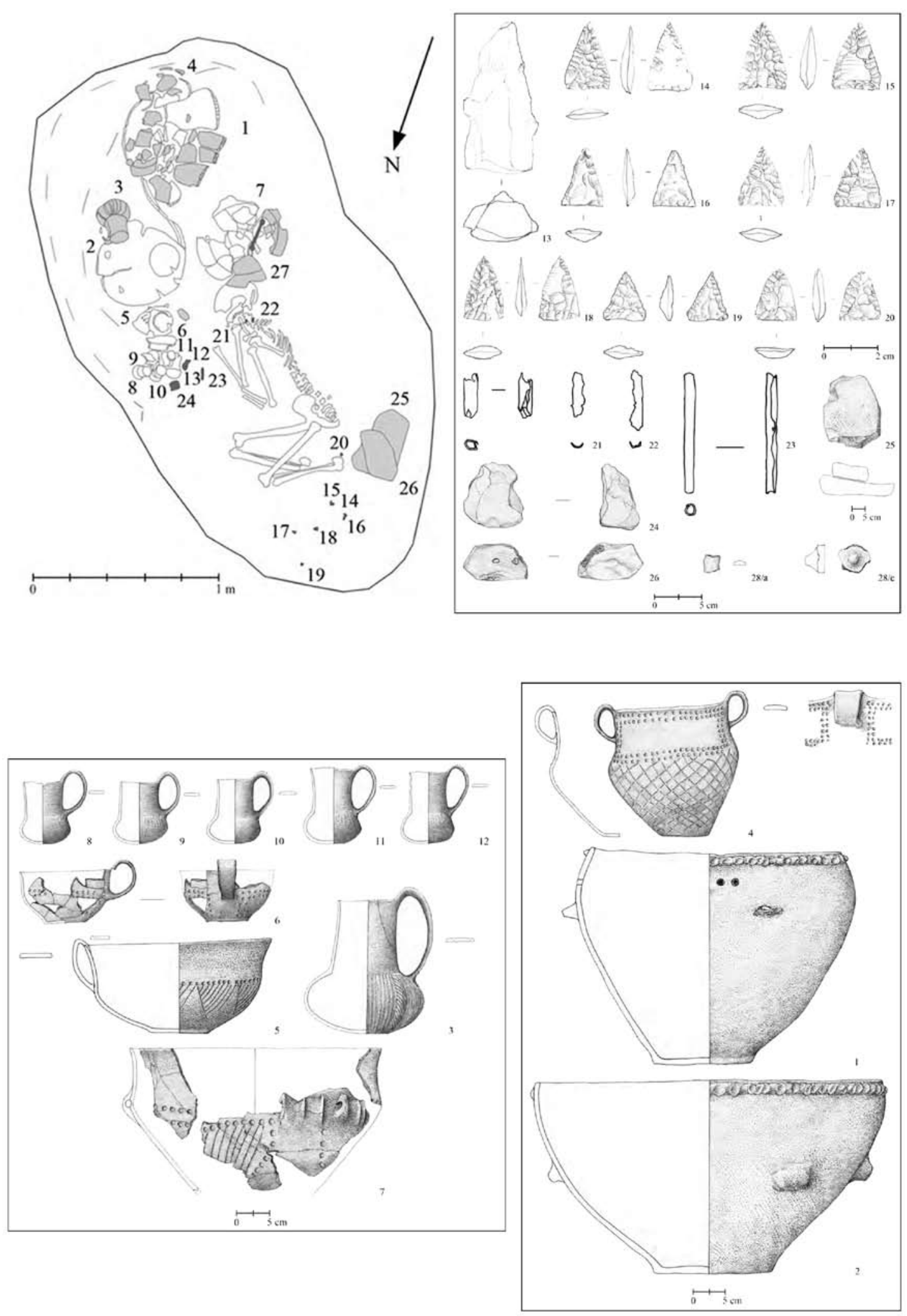

4. ábra. Balatonlelle-Felsö-Gamász, 22. női sír: leletek/mellékletek.

(Nagy Borbála engedélyével, saját képei) 
HARCOSNŐK KLUBJA? - SPECIALIZÁLT TÁRSADALMI HELYZETÜ NŐK

A KÉSŐ RÉZKOR IDŐSZAKÁBAN MAGYARORSZÁGON

NE.

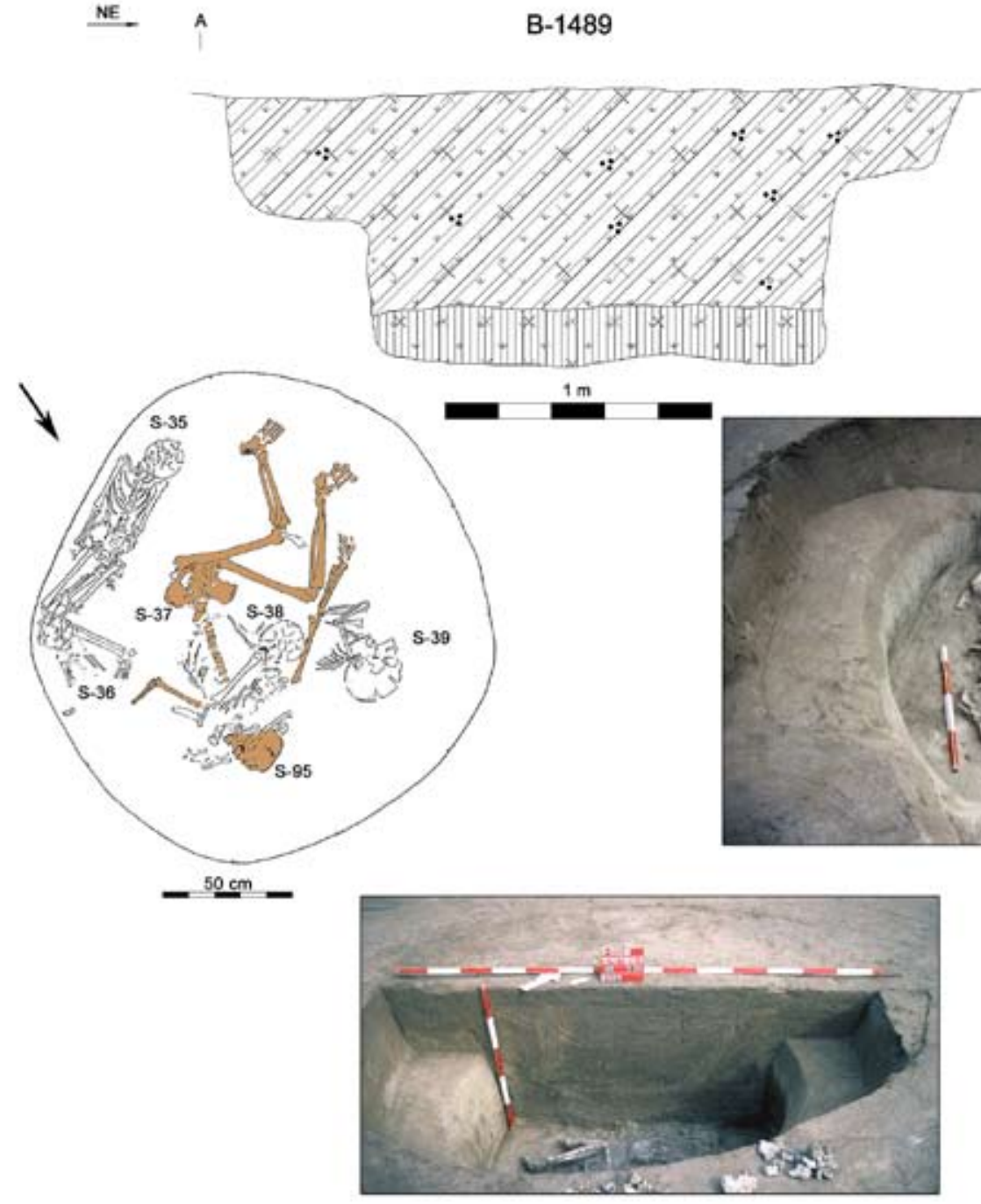

$\underline{\nabla}^{111,44 m}$

$\nabla^{110,40 m}$
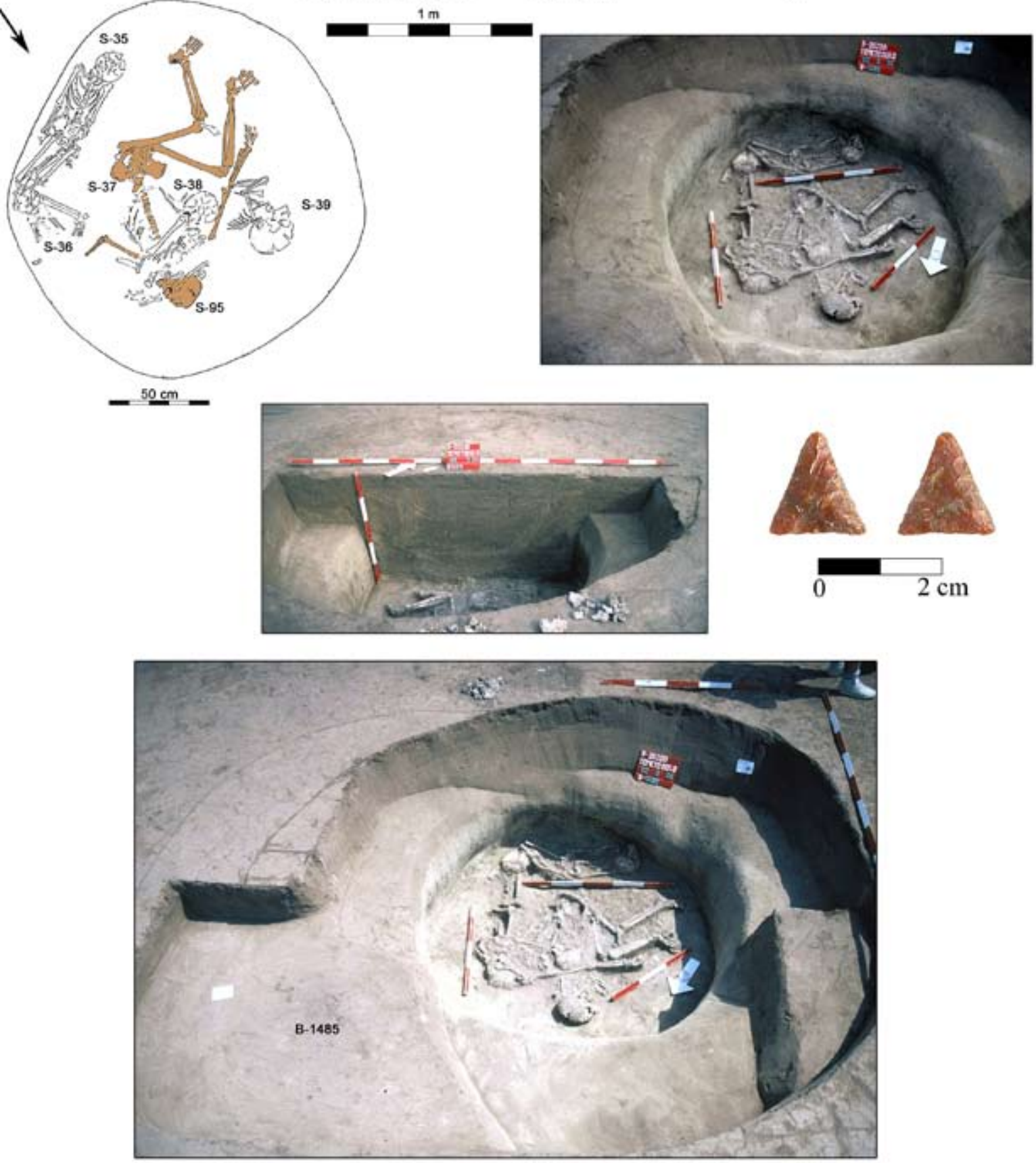

5. ábra. Balatonőszöd-Temetői-dülő, 1489. gödör többes temetkezéssel (a szerző képei) 

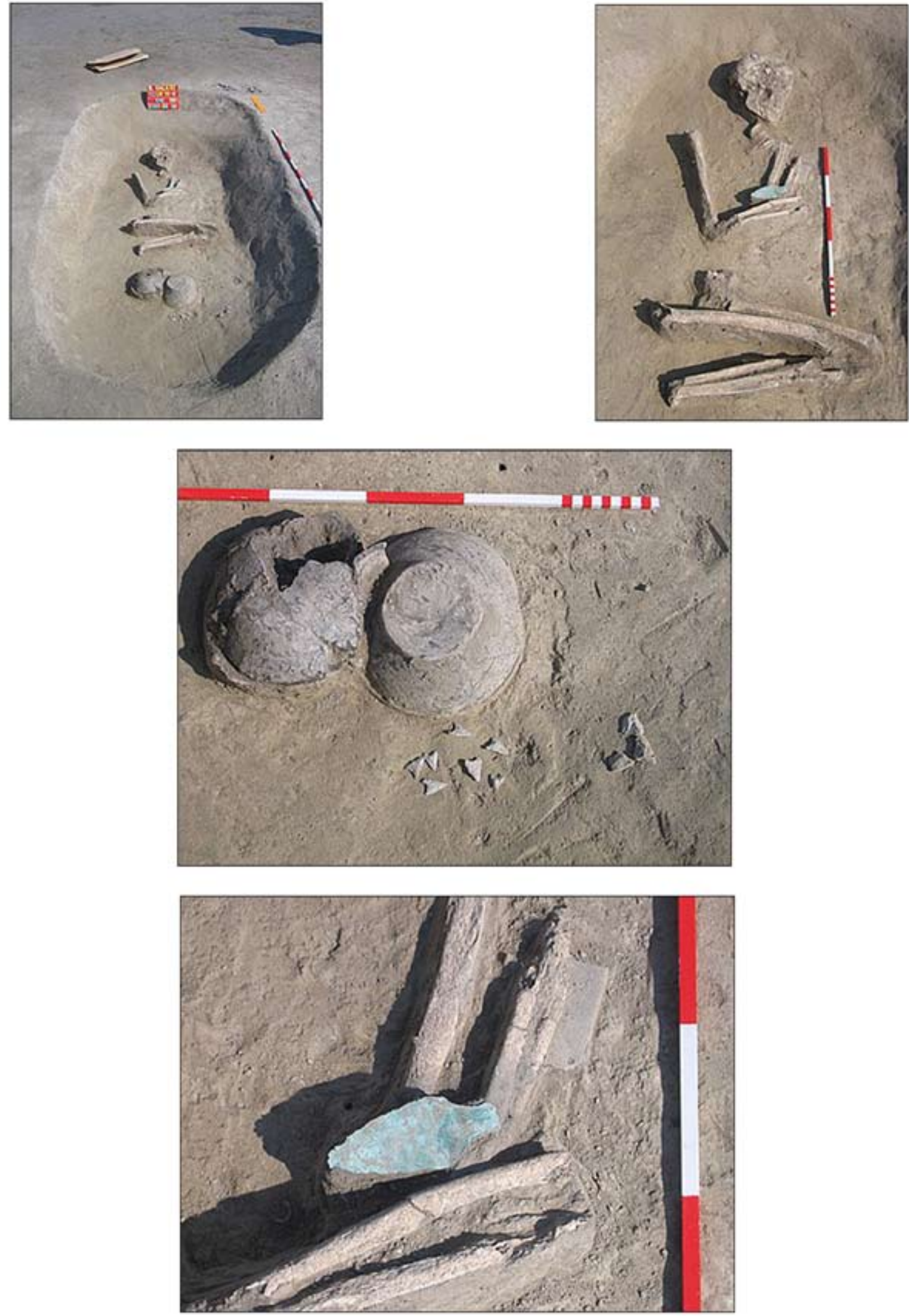

6. ábra. Budakalász, M0-12. Ielöhely, 616. női sír (Czene András engedélyével, saját képei) 


\section{Gödörsíros kurgánok}

Az Alföld területén feltárt kurgánok alatti sírok közül csak a női, és azon belül is a középpontban, tehát alaptemetkezésként előkerült eseteket fogadom el saját korában és közösségében esetleg kiemelkedő státuszú nőként.

- Püspökladány-Kincses-domb: a kurgán alaptemetkezése kecskebőrbe csavart kettős sír volt, nő és gyerek, okkerrög-melléklettel, valamint a kurgán oldalában árokrészlettel. A rítuselemek alapján egy pre-Gödörsíros, ún. Nyizsnemihajlovka temetkezést azonosítottunk. ${ }^{59}$

A férfisírok közül azokat listázom, akik kiemelkedő fegyvermellékletet kaptak.

- Sárrétudvari-Ör-halom: a 7. sírban a 40-59 éves férfi mellett rézcsákány és tőr vagy alabárd (Eschollbrückeni típus) került elő, valamint ezüst és elektron halántékkarikák, mindkettő méltóságjelző lehetett. A temetkezést a 2. felhordási/építési réteghez, de a 3. temetkezési periódushoz kapcsoltuk, késői, Katakombasíros vonásokat mutató Gödörsírosként határoztuk meg. ${ }^{60}$

Következtetésként az vonható le, hogy csak a legkésőbbi időszakban (a rézkor bronzkor közti átmeneti periódusban) jelennek meg azok a temetkezési mellékletek a Gödörsírosok közt, és már Katakomba-hatásra, amelyek olyan fegyver, eszköz és ékszertípusokat reprezentálnak, amely egy harcos uralkodói elithez és akár már egy kialakulófélben levő rangsoroló társadalomhoz kapcsolható, és ez egyelöre csak a férfi-temetkezésekhez köthető. Mindettől függetlenül társadalmilag kiemelkedő státuszt (közösség vezetőjeként vagy megbecsült tagjaként) nők is kaphattak, de ezek még nem jártak rangsoroló mellékletekkel, és pláne nem fegyverekkel.

\section{Harangedényes kultúra}

- Budakalász, M0/12. lelőhely: A lelőhely temető-részén 1070 sír, mellette a hozzá tartozó település került feltárásra. Az előkerült kőleleteket én dolgoztam fel. Ezek alapján állítok össze egy koedukált gyorslistát azokról a sírokról, amelyek fegyvereseket rejthettek. Csak olyan eseteket válogattam be, ahol legalább két, fegyverként számba jöhető lelettípus együttesen került elő, amelyek komplett vadászvagy harcos-készséget alkothattak, és ez már elfogadható valószerüséggel fedheti egy egykori vadász/ harcos kilétét. Ez esetben lehetett először nemek és korok szerinti teljes listát összeállítani, amely az ezek mentén való összehasonlítást is lehetővé teszi. Férfiak:

- 847. sír felnőtt férfi csontvázas sírja három pattintott nyílheggyel, bronz tőrrel és csuklóvédővel.

- 884. felnőtt férfi urnasírja, pattintott nyílheggyel és csuklóvédővel.

Nők:

- 14. felnőtt nő urnasírja csuklóvédővel és bronz tőrrel.

- 616. 23-59 éves nő (?) csontvázas sírja 10 pattintott nyílheggyel, csuklóvédővel és bronz tőrrel (5. ábra).

59 Dani and Horváth 2012, 33-35.

60 Dani and Horváth 2012, 26-32.
Nem meghatározható nemü felnőtt sírok:

- 107. sír urnasír csuklóvédővel és bronz tőrrel.

- 284. urnasír 2 pattintott nyílheggyel, csuklóvédővel és 4 harangedénnyel.

- 945. urnasír 2 pattintott nyílheggyel és csuklóvédővel.

- 1082. csontvázas felnőtt sírja 9 pattintott nyílheggyel, csuklóvédővel és két bronztűvel (talán nő a tű miatt). Gyermek:

- 1118. szórthamvas, 1-7 éves gyermek sírja 7 pattintott nyílheggyel, öntőmintával, csuklóvédővel, kőbaltával.

A teljes temetőelemzésből levonható következtetések alapján elmondható, hogy a fegyvernek minősíthető leletek (nyílhegy, tőr) nem kötődnek nemhez: férfiak és nők is kaphatták mellékletként. Nem kapcsolódnak temetési rítushoz sem: ugyanúgy előfordulnak urnáshamvas, szórthamvas és csontvázas sírokban. Nem kapcsolódnak korhoz sem, hiszen egy egészen kicsiny gyermek sírja az egyik leggazdagabb ebben a tekintetben. A 616. sír a leggazdagabb mellékletü, talán fontos lehet, hogy nehezen meghatározható nemű (férfias, transzvesztita, hermafrodita?) nő volt. A szakirodalomban egyértelműen az íjászattal összekapcsolt csuklóvédők ezen szerepe véleményem szerint kérdéses, mivel ebben a temetőben több esetben kapcsolódnak tőrhöz, mint nyílhegyhez. Talán a puha kőlemez bronz élezésére alkalmas eszköz volt, és nem íjászkodás során csuklót védő tárgy. ${ }^{61}$

\section{Konklúzió}

$A z$ alapvetően tárgyalt három időszakra bontott felosztás szerint haladva megállapíthatjuk, hogy a késő rézkort megelőző időszakban a Kárpát-medencei régészeti kultúrák - különösen a Tiszapolgár, Bodrogkeresztúr és Lengyel - a nemzetközi szakirodalom szerint törzsi társadalmak voltak, amelyekben létezhettek férfitársaságok. ${ }^{62}$ A feltárt sírmellékletek alapján azonban én jóval szerényebbnek látom ezeknek a harciasságát és a jelentőségét, inkább vadászati és hétköznapi célokra viselhettek fegyvert vagy fegyverként is használható eszközöket, és a társaságok leginkább rituális, elsősorban termékenységi és halotti szertartások szervezését végezték.

A késő rézkor időszakában a felbomlóban levő törzsi társadalom a Badenben úgy jelentkezik, hogy megnő és a férfiakéval egyenlően fontossá válik a nők szerepe, amely különösen a rítusok terén nyilvánul meg, de minden bizonnyal a hétköznapi életben is éreztette a hatását, sőt, nyilván onnan került át a szakrális életbe. A férfiklubok/férfitársaságok mellett ezért nagyon valószínű, hogy női, elsősorban termékenységi rítusokkal foglalkozó klubok/társaságok is létezhettek.

A Gödörsíros kurgánok közt a nomád népek mintájára mindkét nem szerepe erős lehetett, de az állatcsordák és a pásztorkodás miatt fokozatosan a férfiak vették át a vezető szerepet mindenben. ${ }^{63}$ Nem tünik

61 Vö. Horváth 2013a

62 Vandkilde 2006

63 Összefoglalóan pl. Davis-Kimball 2002. 
azonban valószínünek, hogy ebben a korai időszakban a nemek szerepe élesen elvált volna, vagy hogy a társadalomban öröklődő ranggal rendelkező rétegek jelentek volna meg, és az sem, hogy az indoeurópaiak sajátosságának tartott hármas társadalmi tagozódás létezett volna (arisztokraták/harcosok/papok). Ezek megjelenése a ma rendelkezésre álló leletek alapján a késői Gödörsírosok Katakombasírosokkal való keveredésének időszakában kezdődött meg. ${ }^{64}$

A Harangedényes kultúrában kezd kialakulni egy elit réteg, amelyben fegyverrel ellátott (íjjal, tőrrel felszerelt) harcosok is találhatók. Mind a férfiak, mind a nők között lehettek harcosok a sírmellékletek szerint, sőt, gyermekek is kaphattak harcos felszerelést a túlvilágra, amely a társadalmi rang öröklődésének lehetőségét és szimbolikus értékét is felveti. Valószínü, hogy már nem csak békés, föleg termékenységrítusokat végző társaságok - amelyek alkalomadtán ad hoc csetepatékat is levezényeltek -, hanem szervezett női és férfi harci klubok/társaságok léteztek, kifejezetten háborús célokra, alkalmakra szerveződve.
Hangsúlyozni kell, hogy a férfiklubok-férfitársaságok és női megfelelőik nem azonosak a harci klubokkal. Előbbiek olyan társadalmakban jönnek létre ahol a nők is elég erősek, mintegy ellensúlyozásaként a másik nem szerepének, és nem katonai célokra szerveződnek elsősorban. ${ }^{65}$ Külső hatásra, külső agresszió esetén alakulnak ad hoc módon harci társasággá, de rövid ideig léteznek, mindössze az incidens idején. ${ }^{66}$ Amennyiben a társadalom fenyegetettsége állandósul vagy ő maga folyamatos expanziót végez (a nomád kultúrák például, de a Harangedényes kultúra is), az elsősorban társadalmi és rituális célokat kiszolgáló társaságok elöször speciális harci klubokká alakulnak, amelyek fokozatosan katonai szervezetté fejlődnek.

Az őskor korai vadásza tehát a késő rézkor folyamán harcossá, majd a késő bronzkor-vaskor folyamán katonává válhat, intézményi szinten a vadásztársaság harci társasággá, harci klubbá majd szervezett katonai kíséretté, hadsereggé. Arról, hogy ez az intenzív vonulat menynyiben tartozik az emberiség és földi világunk fejlődéséhez, a milliónyi eddig e harci kedvnek áldozatul esett, legtöbbször névtelen és ártatlan ember tudna érdemben beszámolni. De persze ők már nem beszélnek...

65 Vandkilde 2006, 360, 379

66 Redmond 1994, 3; Vandkilde 2006, 359

64 Horváth 2011.

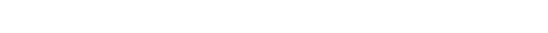




\section{HARCOSNŐK KLUBJA? - SPECIALIZÁLT TÁRSADALMI HELYZETÜ NŐK A KÉSŐ RÉZKOR IDŐSZAKÁBAN MAGYARORSZÁGON}

HARDING A. F. 2007: Warriors and Weapons in Bronze Age Europe. Budapest, Hungary.

HeLbLING J. 2015: Tribale Kriege-Kriege zwischen Dörfern. - In: MellerH. and Schefzik M. (eds.): Krieg. Eine Archäologische Spurensuche Begleitband zur Sonderaustellung im Landesmuseum für Vorgeschichte Halle (Saale). 6. November 2015 bis 22 Mai 2016. pp. 69-83; 83-109. Halle, Germany.

HeYd V. 2007: Families, Prestige Goods, Warriors and Complex Societies: Beaker Groups of the 3rd Millenium cal BC along the Upper and Middle Danube. - Proceedings of the Prehistoric Society 73: 327-379.

HoRvÁTH T. 2004: Late Copper Age Settlement in Balatonőszöd, Hungary. - ActaArchCarpathica 39: 59-85.

HORVÁTHT. 2008: Sozialmorphologische Studie der spätkupferzeitlichen Baden-(Pécel)-Kultur. - Mitteilungen den Anthropologischen Gesellschaft in Wien 138: 159-203.

HORVÁTH T. 2011: Hajdúnánás-Tedej-Lyukas halom. - The Interdisciplinary Survey of a Typical Kurgan from the Great Plain Region: a Case Study (The Revision of the Kurgans from the Territory of Hungary). - In: Barczi A. and Petö Á. (eds.): Kurgan Studies: An environmental archaeological multiproxy study of burial mounds of the Eurasian steppe zone. British Archaeological Reports International Series 2238. pp. 71-131. Oxford, United Kingdom.

HORVÁTH T. 2013A: Budakalász M0/12. kora bronzkori lelöhely kőanyaga (Stone implements of the Bell Beaker cemetery from Budakalász M0/12). - Archeometriai Mühely 2013/X/2: 141-176.

HoRvÁTH T. 2013B: Rezension. M. Bondár - P. Raczky (Red.) The Copper Age Cemetery of Budakalász. - ActaArchHung 64: 331-336.

Horváth T. 2014a: Mobility: Transhumants or Immigrants? - Apulum LI: 99-134.

HORVÁTH, T. (ED.) 2014B: Horváth, T. with contributions by E. Gál, K. Gherdán, S. Gulyás, K. KöHLER, G. KuLCSÁR, Á. KUSTÁR, J. MlHÁlY, I. NAGY, Á. PETŐ, B. PÉTERDI, G. SCHÖlL-BARNA, Gy. SIPOS, É. SVINGOR, M. TÓth, I. VÖRÖs, K. ZANDLER: The Prehistoric Settlement at Balatonőszöd-Temetői-dülö. The Middle Copper Age, Late Copper Age and Early Bronze Age occupations. - Varia Archaeologica Hungarica XXIX.

HORVÁTH T. 2014c: Human depictions in the Age of Transformation, between 4000 and 2000 BC. - South-East European Prehistory 1: $507-544$

HoRváTH T. 2015: Minden másképp van? Tíz év és tíz érv a késő rézkori badeni kultúra kora bronzkorban való továbbélése mellett. - In: Csabai Z., Szabó E., Vilmos L. and Vitári-Wéber A. (eds.): Európé égisze alatt. Ünnepi tanulmányok Fekete Mária 65. születésnapjára kollégáitól, barátaitól és tanítványaitól. pp. 99-171. Pécs/Budapest, Hungary.

HoRvÁTH T. 2018 (Horváth Tünde Bernert Zsolt és Buzár Ágota közremüködésével/With contributions by Zsolt Bernert and Ágota Buzár): Ózd csodálatos földje. A Baden-kultúra Ózd-Piliny variánsa Északkelet-Magyarországon/ The Marvelous Land of Ózd. The Ózd-Piliny Variant of the Baden Culture in North-Eastern Hungary. - Opitz Archaeologica 10

KERIG T. 2010: Ein Statuenmenhir mit Darstellung einer Axt vom Eschollbrückener typ? Zu einem enigmatischen Steindenkmal aus Gelnhausen-Meerholz (Mainz-Kinzig-Kreis) Prähistorische Zeitschrift 85: 59-78.

Konopka T., Szczepanek, A., Przbyta M. M. and Wtodarczak, P. 2016: Evidence of interpersonal violence or a special funeral rite in the Neolithic multiple burial from Koszyce in Southern Poland - a forensic analysis. - Anthropological review 79/1: 64-85.

KÖHLER K. 2015: Anthropological assessment of the Vörs skull. Antaeus 33: 127-127.

KRITSCHER H. 1985: Ein Neolitisches Calvarium mit Trepanation aus Zillingtal. - Wissenschaftliche Arbeiten aus dem Burgenland 71: $37-50$.
MARASzeK R. 2015: Axte und Beile der Bronzezeit: Waffe, Werkzeug, Symbol. - In: Meller H. and - Schefzik M. (eds.): Krieg. Eine Archäologische Spurensuche Begleitband zur Sonderaustellung im Landesmuseum für Vorgeschichte Halle (Saale). 6. November 2015 bis 22 Mai 2016. pp. 285-289. Halle, Germany.

MeLleR H. AND SchefZIK M. (EDS.) 2015: Krieg. Eine Archäologische Spurensuche Begleitband zur Sonderaustellung im Landesmuseum für Vorgeschichte Halle (Saale). 6. November 2015 bis 22 Mai 2016. Halle, Germany.

Meyer C., Brandt G. D., HaAk W., Ganslmeier R. A. and Meller H. 2009: The Eulau eulogy: Bioarcheological interpretation of letha violence in Corded Ware multiple burials from Saxony-Anhalt, Germany. - Journal of Anthropological Archaeology 28: 412-423.

NAGY B. 2010: Gräberfeld der Badener Kultur in Balatonlelle-Felső Gamász. - Antaeus 31-32: 375-498.

PARKInson W. A. AND GYucha A. 2007: A késő neolitikum-kora rézkor átmeneti időszakának társadalomszerkezeti változásai az Alföldön. Rekonstrukciós kísérlet (Die Veränderungen in der Gesellschaftsstruktur der Übergangsperiode vom Spätneolithikum zur frühen Kupferzeit in der Grossen Ungarischen Tiefebene). - Archaeológiai Értesítő 132: 37-81.

Redford E. 1994: Tribal and Chiefly Warfare in South America. Ann Arbor, USA.

SACHSSE C. 2011: Burial Mounds in the Baden Culture: Aspects of Local Developments and outer Impacts. - In: Müller-Cerka S (ed.): Ancestral landscapes. TMO 61, Maison de l'Orient et de la Méditerranée, Lyon. pp. 127-134. Lyon, France.

SAILE T. 2014: Ein Kampf um Altheim? Zur Unschärfe vorgeschichtlicher Lebensbilder. - In: Link T. and Peter-Röcher H. (eds.): Gewalt und Gesellschaft. Dimensionen der Gewalt in ur- und frühgeschichtlicher Zeit. Universitätsforschungen zur Prähistorischer Archäologie 259. pp. 225-236. Bonn, Germany.

STAMBowskı M. 2015: Nicht nur für die Jagd - Pfeil und Bogen in der Vorgeschichte. - In: Meller H. and Schefzik M. (eds.): Krieg. Eine Archäologische Spurensuche Begleitband zur Sonderaustellung im Landesmuseum für Vorgeschichte Halle (Saale). 6. November 2015 bis 22 Mai 2016. pp. 131-135. Halle, Germany.

TótH G. 2011: A rézkor embertani emlékei Vas megyében. - Folia Anthropologica 10: 90-101

VANDKILDE H. 2006: Warriors and Warrior Institutions in the European Copper Age. - In: Otto T., Thrane H. and Vandkilde H. (eds.): Warfare and Society. Archaeological and Social Anthropological Perspectives. pp. 393-422. Aarhus, Denmark.

VENCL S. 1984: War and Warfare in Archaeology. - Journal of Anthropological Archaeology 3: 116-132.

WAHL J. 2010: Wenige Knochen, viele Fragen. Auf der Suche nach den Menschen der Michelsberger Kultur. - In: Jungsteinzeit im Umbruch. Die „Michelsberg Kultur” und Mitteleuropa vor 6000 Jahres. Ausstellungkatalog, Badisches Landesmuseum, Karlsruhe. pp. 96-104. Karlruhe, Germany.

WAHL J. \& TRAUTMAN I. 2012: The Neolithic massacre at Talheim: a pivotal find in conflict archaeology. - In: Schulting R. and Fibiger L. (eds.): Sticks, stones and broken bones: Neolithic violence in an European perspective. pp. 77-100. Oxford, United Kingdom.

ZÁротоскY M. 1992: Streit-äxte des mitteleuropäischen Äneolithikums. - Quellen und Forschungen zur prähistorischen und provinzialrömischen Archäologie 6, Acta Humaniora, Weinheim.

ZICH B. 2015: Der Stabdolch - Herrschaftssymbol oder Waffe? - In: Meller H. and Schefzik M. (eds.): Krieg. Eine Archäologische Spurensuche Begleitband zur Sonderaustellung im Landesmuseum für Vorgeschichte Halle (Saale). 6. November 2015 bis 22 Mai 2016. pp. 275-279. Halle, Germany.

K. ZoFFMANN Zs. 2004: A bronzkori kisapostagi kultúra embertani lelete Ordacsehi-Csereföld lelöhelyröl. - In: Ilon G. (ed.): Halottkultusz és temetkezés. MOMOS III. Öskoros Kutatók III. Összejövetelének konferenciakötete. pp. 383-390. Szombathely, Hungary. 


\title{
Fightress clubs? Women with a special social status in the Late Copper Age in Hungary
}

\author{
TÜNDE HORVÁTH
}

In this study, my focus is on the social position of women in the Baden complex and the Yamna culture, the two dominant macro-regional cultures of the Late Copper Age (3600-2800 BC) and the ensuing transitional period (2800-2600 BC) in Hungary in the light of the archaeological record.

Although the Beaker population is assigned to the Early Bronze Age (2500-1900 BC) in the Hungarian chronological system, it is dated to the Late Neolithic/ Late Copper Age and the Reinecke A0 in other regions of Europe where this culture was distributed, and I have therefore included it in my analysis.

My comparison is thus based on a complex body of evidence: on the cultures living simultaneously in a region on the one hand, and on successive cultures on the other, which also affords a look at differently organised societies as well as at certain diachronic tendencies.

Viewed from another perspective, we can only shed light on the social position of women if we are familiar with the social position of the period's men.

There, I have searched for the signs of aggression and violence in the three cultures examined here, and I have identified former charismatic persons who can be plausibly associated with warfare and battling.
Obviously, we generally single out cases, which for one reason or another seem special to us as archaeologists: unique, particularly striking phenomena and finds. At the same time, the retrojection into prehistory of cases that appear to be unusual can be a source of many pitfalls in interpretation. Ultimately, only so much can be said that in all three cultures studied here, there were women occupying a special position in their societies - either owing to their profession, their wealth, or their knowledge - who visibly rose above the average in a manner that is still discernible today. This stereotype is as old as human society, a phenomenon attested in every age. Being an intrinsic part of human nature, aggression and violence can be documented from the Palaeolithic onward. We can only draw meaningful conclusions regarding the period discussed here if we also examine the societies of the preceding and ensuing periods, enabling the identification and assessment of possible salient changes as well as the continuity of existing traditions on the tendency level. 